\title{
Cardenal uno y muchos: la polifonía del discurso en su obra ${ }^{1}$
}

\author{
$\mathrm{M}^{\mathrm{a}}$ Ángeles Pastor Alonso ${ }^{2}$
}

Resumen. En la poesía de Ernesto Cardenal se aprecian múltiples discursos: por un lado las voces exteriores u objetivas, que actúan con funciones diversas; por otro, la aparición de una voz personal, con tendencia creciente al autobiografismo; y el poeta actúa también a menudo como transmisor de otros discursos ajenos. De este modo abre su obra a un despliegue intertextual que multiplica las posibilidades de la lectura e involucra al lector en la construcción del poema. Se trata en este artículo de sistematizar estas voces o modulaciones poéticas y de rastrear su práctica a lo largo de la extensa obra poética del nicaragüense, con atención especial a su libro más representativo, Cántico cósmico. Palabras clave: Ernesto Cardenal; ciencia; mística; intertextualidad; exteriorismo.

\section{[en] Cardenal, one and many: polyphony in his work}

\begin{abstract}
This paper intends to discern the multiple voices present in Ernesto Cardenal's poetry. Outer objective voices with different intentions are present in his work together with a personal voice which increasingly tends to autobiographical experience. In addition, the transmission of other authors' messages is frequent too. This way, his work is opened to intertextuality, multiplying thus the chances for different readings and involving the reader in the building of the poem. In this paper we aim to systematize the different voices and to trace them throught his extensive poetic production, focusing on his most representative book, Cántico cósmico.
\end{abstract}

Keywords: Ernesto Cardenal; science; mystics; intertextuality; exteriorism.

Sumario: 1. La voz enmascarada. 2. La voz personal: lo autobiográfico y lo místico. 3. La voz del testigo. 4. La voz didáctica. 5. La voz profética. 6 . La voz del lector. 7. ...y la del poema.

Cómo citar: Pastor Alonso, Ma.A. (2021) Cardenal uno y muchos: la polifonía del discurso en su obra, en Anales de Literatua Hispanoamericana 50, 201-211.

Hay un aspecto de la poesía de Ernesto Cardenal lo suficientemente atractivo como para permitir un acercamiento único, y a la vez diverso y plural. Paul Borgeson, referencia ineludible en los estudios cardenalianos, ya sugería en su clásico libro Hacia el hombre nuevo que los poemas del nicaragüense tenían una estructura análoga a la de la fuga musical (1984: 78); años más tarde, después de la publicación de Cántico cósmico, insistió en afirmar que este autor, "más que ningún otro en lengua española, convierte la pluma del poeta en la batuta del director sinfónico" (Borgeson, 1992). Afirmación que puede transformarse enseguida en pregunta: ¿dónde, y cómo, se percibe esa música coral que brota de estos versos?

Una lectura aunque sea superficial de la obra de Cardenal impacta por la variedad y amplitud de las interpolaciones que se incluyen, extraídas de materiales diversos. El nicaragüense nunca ha ocultado sus fuentes: versos de los poetas más dispares, obras históricas, antropológicas, filosóficas o teológicas, y por supuesto textos científicos, de física, astronomía, biología... Eso lo convierte en un autor bastante diferente. Como algún crítico ha observado (Carrasco: 2004), en sus libros el discurso típico de la poesía se altera y sustituye por discursos de disciplinas no literarias. Por otra parte, Cardenal se sirve a menudo de estructuras no lineales, de yuxtaposición o contraste, como técnica básica de construcción poética. Suele utilizarse el

\footnotetext{
${ }^{1}$ Artículo derivado de la conferencia inaugural en la Jornada de Estudio en honor del poeta Ernesto Cardenal (Universidad de Salamanca, 15 de mayo de 2013), con motivo de la concesión del Premio Reina Sofía de Poesía Iberoamericana.

2 Universidad de Huelva. España.

E-mail: marpasalo@gmail.com
} 
término collage, ${ }^{3}$ a la manera poundiana, para denominar genéricamente estos recursos. Son aspectos estilísticos que acreditan también la multiplicidad de voces de sus poemas, que son, en realidad, mucho más complejos de lo que sugeriría el lenguaje tan esencial y sencillo como el que muestran a primera vista.

El mayor problema no radica en dar por sentada esta teoría de la discursividad múltiple, del Cardenal uno y muchos a un tiempo, sino en rastrear su práctica en poemas específicos. Este propósito implicaría no sólo hacer las mismas y amplísimas lecturas del poeta, en antropología, historia, teología y, sobre todo, ciencia (él mismo confiesa que es lo que más le atrae desde hace tiempo, leer obras científicas), sino además revivir su misma vida, ya que uno de las contenidos de su obra son los acontecimientos de carácter privado llamémoslos así- que elige incorporar en su poesía. Y estas que mencionamos son sólo algunas de las múltiples fuentes de la extraordinaria polifonía que tipifica la poesía de Cardenal. En cada obra, pero también en cada poema, predomina un tono, ya sea político, o científico, o profético, o acentuadamente místico, que es a su vez la fusión de muchas voces, de muchos hablantes interpolados. El coro, forzosamente, no suena igual en todos los momentos.

Esta es una de las muchas características estilístico-narrativas que hacen del poema de Cardenal algo proteico y dinámico, y proporciona un reto especial al lector cuya colaboración para construir el poema es indispensable. Por cierto, ¿qué lector? ¿Piensa Cardenal en un perfil, un destinatario concreto? Y enseguida surgen más preguntas: ¿Qué implicaciones tiene esta pluralidad de discursos? ¿Quién "pone orden" entre tantas voces? ¿Puede distinguirse algún "solo" entre ellas? ¿Y quién piensa el autor que debería escucharlas?

Cuestiones de esta índole son las que se intentan responder aquí. Nos asomamos, hay que advertirlo, a la íntima contextura de la creación poética, y sobre todo, a la forma personal en que el artista modela sus materiales. Las distintas voces con que Cardenal habla en sus versos revelan, en grados distintos, la relación que establece con su propia obra, como productor del discurso y como sujeto que actúa en el propio discurso. Una perspectiva doblemente sugerente, pues nos permitirá comprobar cómo el poeta ejerce de responsable de las operaciones puestas en marcha a lo largo del texto y también cómo se presenta a sí mismo.

\section{La voz enmascarada}

Puede decirse, grosso modo, que en la obra de Cardenal se da una colaboración de dos niveles discursivos: por un lado los discursos públicos, o exteriores, objetivos; es decir, todas esas voces proféticas, testimoniales, didácticas, etc; y por otro, los discursos privados, o subjetivos, con una tendencia creciente al autobiografismo en su poesía última. A estos dos niveles habría que añadir los discursos indirectos, es decir, aquellos en que el poeta no el emisor original sino que actúa como simple transmisor, y cuya variedad es casi infinita.

Comenzamos por estos últimos. Desde los inicios de su actividad literaria, tras el descubrimiento de la poética de Pound, Cardenal decide adoptar el punto de vista, el tono y el lenguaje de sus personajes poéticos para enmascarar lar su propia voz. No hablamos solo de procedimientos intertextuales -la presencia de citas, por ejemplo- que abundan ya desde Hora cero (1960). Se trata de recursos más arriesgados, como la reescritura del discurso ajeno situado en un contexto diferente -iqué otra cosa son los Salmos, o Epigramas?; o bien, el empleo de yuxtaposiciones de índole diversa para iluminar a la luz del presente lo que dicen los actores del pasado. Así sucede, por ejemplo, en El Estrecho dudoso, obra en la que diversos cronistas (Colón, Bernal Díaz, Bartolomé de las Casas...) asumen la responsabilidad de relatar la historia de la búsqueda de un canal interoceánico. Recuérdese igualmente el estimulante acercamiento al príncipe-poeta Netzahualcoyolt, personaje que funciona como alter ego del poeta (López-Baralt, 2012: 71) en la serie "Cantares Mexicanos", de Homenaje a los indios americanos. La técnica de apropiación le sirve a Cardenal, además, para difundir el encanto de la poesía náhualt:

Del cielo viene el cantor

Del interior del cielo las flores y los cantos

sí, de su Interior. Brotan flores, brotan flores

de mi atabal. Flor-Canto son mis palabras.

\footnotetext{
${ }^{3}$ Saúl Yurkievich (1996: 335) sienta la base de la influencia de esta técnica en su generación, y reconoce que "Ernesto Cardenal trasplanta a la poesía hispanoparlante los dispositivos poundianos". Véase también Borgeson (1984: 100).
} 
Yo ando siempre cantando. No ando en Propagandas

Tú estás en estos cantos Dador de la Vida.

Distribuyo mis flores cantos a mi pueblo, -les riego poemas, no tributos.

Que no cante yo en vano.

(Cardenal, 1992: 12)

A estos propósitos de carácter histórico habría que sumar el impulso de la ciencia a partir de Cántico cósmico. Aunque ya antes hubiera una propensión hacia lo científico en la obra de Ernesto Cardenal, es en este magno proyecto cuando sus versos se llenan de leyes físicas o teorías cosmológicas:

Newton pensando en ese borde.

Rechazando ese borde.

Tras el que habría un vacío oscuro sin límites ni fronteras.

Y Einstein:

No hay centro ni borde aunque la superficie es finita.

Un universo curvado que se junta en el lado opuesto.

En él las galaxias girando

girando como gigantescas girándulas de radiación.

En un universo infinito

habría infinitos planetas habitados

e infinitos nosotros mismos.

(Cardenal, 1989: 88)

En la mayoría de los casos suele haber un desplazamiento de la primera persona, con el que Cardenal se apropia de la voz del protagonista de la historia o del creador de la teoría científica, a través de una máscarapoema plenamente asumida. De este modo actúa como receptor y a la vez como transmisor, explica la profesora Pérez López (2012: 50). Progresivamente nuestro autor ha ido ensayando a través de esos múltiples personae el más difícil todavía del enmascaramiento poético, de la poesía objetiva y exterior; y cuanto más se avanzaba en este camino con más claridad se definían las coordenadas que han sostenido su visión del mundo y su misión como poeta. Como sentenció hace tiempo Cintio Vitier (1979: ix), "expresando el mundo que lo rodea y sus raíces históricas, Cardenal se ha expresado también insuperablemente a sí mismo".

Este es un recurso, por cierto, que ya se había gestado en sus primeros poemas históricos, escritos en los años cincuenta del siglo pasado: "Raleigh", "Los filibusteros", "Con Walker en Nicaragua", etc. En ellos Cardenal realiza un acercamiento a lo propio a través de una óptica foránea como recurso para lograr un imprescindible distanciamiento. El poeta planea sobre el devenir histórico del continente, abarcando un periodo histórico amplísimo y haciendo calas en personajes o episodios de las más diversas procedencias: desde el primer cónsul norteamericano en Nicaragua hasta el propio Bolívar. Se utiliza el ojo ajeno, y también la voz ajena, para comunicar poéticamente una realidad misteriosa, en último extremo inefable. "Están enfermos de eternidad", dijo de estos personajes Ariel Dorfman (1988: 108). Quizás aquí, antes que en otros poemas, hay que empezar a rastrear ese hambre de Absoluto que guiará años después la trayectoria poética del nicaragüense por el desolado territorio de la noche oscura, convirtiéndolo, como se ha dicho, en uno de los místicos de expresión más original de la literatura contemporánea, fundador de la mística hispanoamericana (López Baralt, 2012: 24).

\section{La voz personal: lo autobiográfico y lo místico}

En este salto del enmascaramiento poético a la comunicación de sus experiencias personales, incluso espirituales, más íntimas, se percibe un cambio tan notable que resulta muy tentador asomarse a la forma en que se consuma esa transformación. El yo silente, implícito, enmascarado, de buena parte de su poesía se trasmuta, en obras posteriores, en un yo rotundamente autobiográfico:

Los que tenemos los brazos sin abrazos [...]

Mis condiscípulos se rieron

cuando grité al padre Otaño venir a ver el fenómeno

de dos insectos pegados de la cola. 
En otra etapa de mi vida

he envidiado no sólo a mi niñez perdida sino

a los insectos.

(Cardenal, 1993: 43-44).

Esta voz autobiográfica es, sin duda, la más novedosa de la madurez poética de Cardenal. Porque esos discursos privados, o subjetivos, aunque constituyen la fuente más notoria de la lírica de todos los tiempos no han estado muy presentes en la obra del nicaragüense, más bien han sido extraños a ella. Él, que hizo de la poesía "austeramente fiel a la realidad objetiva y exterior" (Cuadra, 1971: 20) su seña de identidad, y que la definió como una "poesía de las cosas, de los nombres propios y las cifras y hechos y dichos" (Cardenal, 1986: viii), ha ido sintiendo paulatinamente la necesidad de poetizar acontecimientos más suyos, rescatando una voz personal. Y el hablante de sus versos se hermana poco a poco con su yo real y empírico.

En Vuelos de victoria, una colección de textos escritos en los años pre y postrevolucionarios (década de los 70 y principios de los 80 ), ya se preludiaba esta nueva dicción, inclinada a una mayor intimidad. Esos poemas se integraron después en Cántico cósmico (1989), obra en la que eclosiona un progresivo autobiografismo, seguramente ligado al aumento de los juegos intra y extratextuales en su poesía (Borgeson, 2010). Así, justo en su obra más épica, donde la ciencia asume el protagonismo de conducir al lector desde las galaxias del espacio exterior hasta las células microscópicas de nuestro ADN, las cantigas se entreveran, dice Luce López Baralt (2012: 66), “de acotaciones personalísimas en las que el antiguo 'exteriorismo' objetivista parece por momentos estrenar una entrañable, novedosa subjetividad". O dicho de otro modo, Cardenal ha encuentra la manera de fundir exitosamente, en una sola voz, la ciencia con el misticismo.

La introducción de estos materiales autobiográficos puede entenderse desde la necesidad de equilibrar otros elementos más objetivos e impersonales. En alguna conversación (Pastor, 1998: 218-19) Cardenal ha reconocido que ciertamente en su poesía anterior -anterior al Cántico cósmico, o al menos anterior a la revolución sandinista- casi no había tocado esos temas por cierta especie de pudor sobre su propia intimidad, y también porque su poesía tenía la tendencia de ser exterior, no interiorista. Pero que conforme iba gestándose este largo poemario e iba creciendo -tal vez igual que se expandió el universo-, fue viendo necesario incluir ciertos elementos para balancear otros, y se dio cuenta de que no podía faltar lo autobiográfico. Desde luego, esta pudo ser una exigencia extrínseca, pero en realidad habría que sumarla a la gradual inclinación del autor a convertirse a sí mismo en materia poética. También en materia narrativa, por cierto, de ahí la publicación paralela de los tres volúmenes de sus memorias ${ }^{4}$ que detallan el itinerario de una vida intensa.

El caso es que, a partir de Cántico, Cardenal retoma el hilo de la evocación lírica y nostálgica, cuarenta años después de haberlo abandonado al cerrar su poema "La ciudad deshabitada", con el que selló lo que podría llamarse su prehistoria poética. En este fragmento, que recuerda una anécdota de juventud, la mención a Neruda ofrece la clave de la mayor influencia de aquellos primeros ensayos poéticos; muy poco después del momento evocado en estos versos fue cuando se dio el significativo viraje hacia la nueva actitud estética que ha orientado toda su poesía posterior:

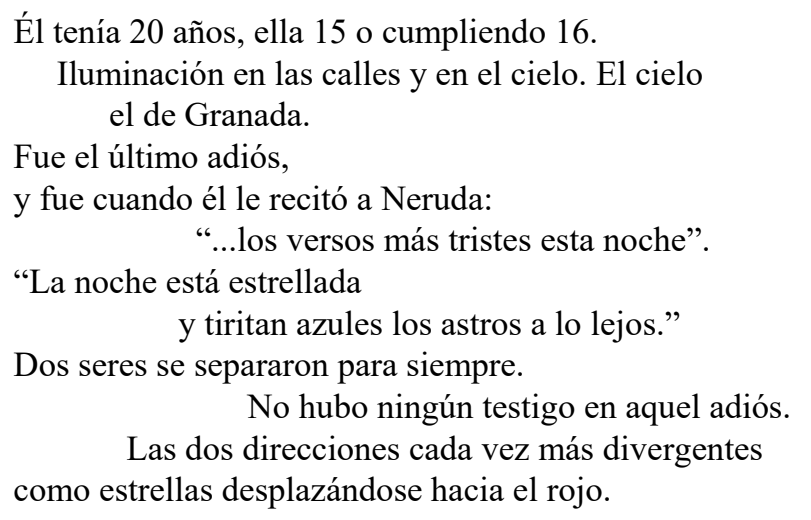

\footnotetext{
${ }^{4}$ Comenzaron a publicarse desde 1999 en editoriales españolas y americanas a la vez. Actualmente pueden encontrarse completas en el catálogo de Fondo de Cultura Económica y de Trotta, su editorial española: Vida perdida (2005), Las ínsulas extrañas (2002) y La revolución perdida (2004).
} 
He pensado otra vez en vos, porque la noche está estrellada y miro temblar los astros a lo lejos con su luz azulosa.

(Cardenal, 1989: 43)

Son varias las funciones que cabe atribuir a esta voz autobiográfica. En primer lugar debe hablarse de una finalidad catártica, un desahogo de sus renuncias humanas, que según confiesa, "todavía chorrean sangre" (1993: 66). Abundan los versos que destilan confesiones liberadoras, a través de las cuales se asoma una voz en conflicto, muy distinta de la sólida voz de sus obras más políticas o de la apasionada que recorre las raíces de la historia americana. El poeta admite que "El propósito de mi Cántico es dar consuelo/También para mí mismo ese consuelo./ Tal vez más." (Cardenal, 1989: 548). Y ese consuelo se decanta a través de la creación poética. En otro poema de Telescopio dialoga con Dios de esta forma:

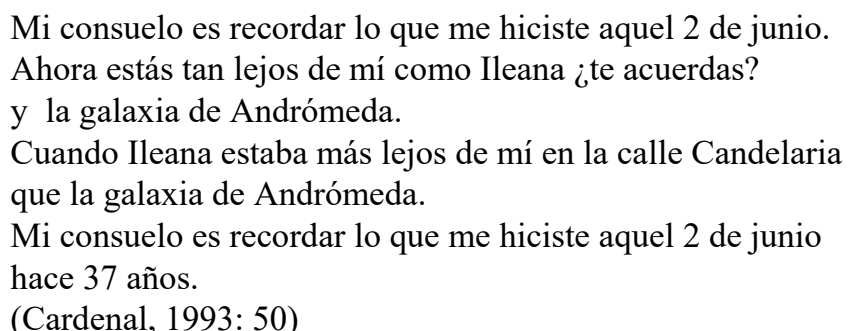

A menudo, en versos como estos, el recuerdo de sus vivencias amorosas o experiencias de su infancia y juventud converge con la preocupación por el paso del tiempo, uno de los temas recurrentes con un enfoque más personal en el conjunto de la obra cardenaliana. La perspectiva autobiográfica imprime inmediatamente al discurso una fuerte emotividad:

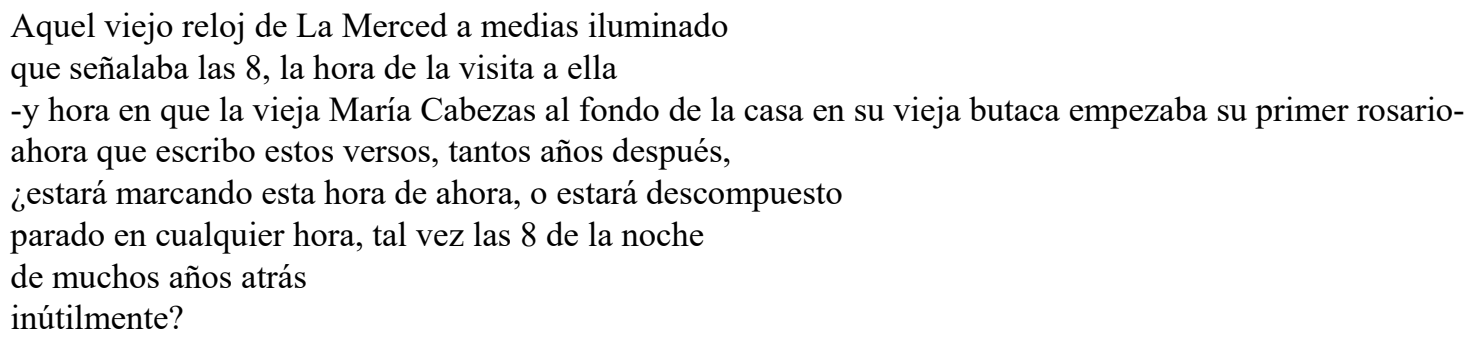

(Cardenal, 1989: 49)

Hay otros pasajes autobiográficos que frisan, de una u otra forma, el motivo del celibato. López Baralt, estudiosa de la vertiente mística de la poesía de Cardenal, dice a propósito de la franqueza de estas confesiones que son "de excepcional importancia, ya que rompe[n] con dos milenios de silencio cristiano al respecto" (2012: 73). Estamos ya escuchando la melodía más íntima, más cálida y más desnuda expresivamente desnuda también- de la polifonía discursiva que analizamos; y al tiempo es posible asomarse, no sin sorpresa, a la experiencia vivencial, dinámica, de un Amor con mayúsculas.

Los detalles de esta dimensión espiritual, contemplativa, desde donde hay que reubicar, según LópezBaralt, la escritura de la obra de Ernesto Cardenal, han ido emergiendo poco a poco. Primero desvinculados de su yo privado en las reflexiones de Gethsemay, Ky; acusando después una crisis purificativa en Cántico cósmico; y cantando después, en éxtasis transformante, la posesión no sensible de Dios. Aparece incluso una visión suavemente irónica sobre sí mismo que es también muy novedosa:

El que amó más que todos sus compañeros,

el que amó más en toda su generación,

amando ahora un tal ser trascendente,

como decir un tipo no existente.

En qué has venido a parar, Ernesto.

(Cardenal, 1993: 48)

Todas ellas son inflexiones de un discurso poético que brota, fiel a sus orígenes, de la interacción continua de fragmentos intertextuales, pero en el que -hay que insistir de nuevo- el yo lírico no había tenido antes tan notoria presencia, pues se hallaba difuminado, quizás elidido. Tras el solo instrumental de Telescopio..., el salto entre las voces objetivas y subjetivas que siguen entreverando los versos de Cardenal se realiza de 
forma más fluida, con mayor equilibrio entre el lenguaje de la ciencia y el del recuerdo. Así lo hace notar $\mathrm{M}^{\mathrm{a}}$ Ángeles Pérez López (2012: 80-81) al hablar de Versos del pluriverso ${ }^{5}$, un poemario escrito en plena madurez:

Dicen que habiendo infinitud de mundos

Hay un mundo en que Napoleón venció en Waterloo.

Y un mundo en que ella aceptó mi amor en Granada.

Pero esos mundos y el nuestro no se juntarán jamás.

(Cardenal, 2005: 11)

\section{La voz del testigo}

Hablemos ahora de otros pasajes que también introducen referencias autobiográficas pero que son ya un puente hacia un tipo de discurso más objetivo. Cardenal actúa en ellos a la manera de un ubicuo reportero que ofrece su propia versión de los hechos, puesto que los ha vivido personalmente o ha sido observador privilegiado. En estos casos el yo del poeta se emplea como criterio de autoridad para refrendar la validez del mensaje, le confiere credibilidad. Este yo testimonial, que se distingue del propiamente lírico, ejerce una función similar a la del cronista que da fe de ciertos acontecimientos de la historia contemporánea y aporta argumentos para que los lectores puedan, a su vez, formarse sus propios juicios.

Hace muchos años, cuando escribió Hora cero, Cardenal no pudo -o no quiso- eludir este enfoque puntual en unos versos célebres: "Yo estuve con ellos en la rebelión de abril/ y aprendí a manejar una ametralladora Rising. Y Adolfo Báez Bone era mi amigo". En obras más recientes, la opción por esta voz poética, por este discurso intermedio entre lo público y lo privado, aflora deliberadamente en bastantes pasajes de carácter político de Cántico cósmico (escenas de la cantiga "Documental Latinoamericano", o el relato de sus visitas a los campos de concentración nazis pueden servir de ejemplo); también en algunos poemas recogidos en Pasajero de tránsito (2009), una colección muy bien trabada que confiere unidad a textos de diversa temática y épocas diferentes; y, cómo no, en la visión que Cardenal ha ofrecido sobre la revolución sandinista, uno de los hilos poéticos de procedencia autobiográfica que tejen el tapiz de su obra.

En el poema "Ocupados", por ejemplo, que formaba parte de Vuelos de victoria, Cardenal insiste en que todas esas vivencias colectivas tan intensas de aquellos primeros días de la revolución quedarán "para quien quiera verlo en los viejos periódicos/en periódicos amarillos el comienzo de la nueva historia/ periódicos poéticos/ allí verán en hermosos titulares lo que yo ahora digo..." ${ }^{\prime 6}$ (1989: 189). Habiendo sido tan remiso a hablar de sí mismo, esta particular crónica le resulta muy propicia: proporciona el tono adecuado para combinar lo personal -las vivencias subjetivas- con experiencias que él desea objetivar proporcionándoles una dimensión más colectiva. Si nos fijamos bien, no estamos lejos del discurso profético de Salmos, donde el poeta actúa como vox populi, voz del pueblo; o de la voz histórico-narrativa de otras obras épicas suyas. Lo nuevo que añade Cardenal es la indicación de que esa materia poética, de posibilidades ilimitadas según las pautas exterioristas, ahora procede también de su propia vivencia personal.

\section{La voz didáctica}

Todavía hay, por supuesto, otras voces de carácter más público en la obra última de Cardenal. Es importante hablar, entre ellas, de la voz didáctica, que conecta con la intención declarada de interpretar los acontecimientos para sus lectores y que en parte es consecuencia de un estilo que opta por la inteligibilidad poética y rechaza cualquier tentación de oscuridad. En el poema "8 Ahau", de la colección de poemas indios, había declarado expresamente: "Mi deber es ser intérprete./ Vuestro deber (y el mío) es nacer de nuevo".

\footnotetext{
${ }^{5}$ En la misma línea indica Luce Lopez-Baralt: "en este libro el poeta va a poner la astrofísica directamente al servicio de sus reflexiones místicas" (2012: 107).

6 Y en efecto, 22 años después Cardenal rescató aquellos viejos periódicos de 1979 para escribir el tercer volumen de sus memorias (Managua, Anamá, 2003), sintiendo una inmensa tristeza por esa Revolución perdida y reescribiendo casi literalmente la experiencia personal y colectiva que narraba aquel poema (p. 332). El yo autobiográfico sin ambages que ordena el discurso de estas memorias recoge la declaración que aquel otro yo narrador-testigo había ofrecido.
} 
Cuando lo que hay que interpretar son los enigmas del universo, o los misterios de la ciencia contemporánea, a veces tan llenos de poesía pero casi siempre tan inescrutables, el discurso se vuelve denso, reiterativo y es necesario recurrir a constantes ejemplificaciones. Véase, por ejemplo, el inicio del poema "Universo de 3 libras", de Versos del pluriverso:

Las estrellas que tú ves están en tu retina, mi amiga.

En la bóveda celeste de tus ojos.

Y si miro el pasto, las montañas, como si estuvieran afuera, no miro nada afuera sino su imagen en mi pupila. Y si te miro a ti como afuera (hablando ahora en este restaurante) te miro sólo en mi pupila. Y tocarte, si es que yo te tocara, no sería que tocara tu piel sino la mía, sus vibraciones en mi cerebro. No es que no existas afuera, verdadera, amiga mía, pero tu realidad dentro de mí es ilusión.

(Cardenal, 2005: 37)

El yo didáctico, muy ligado últimamente a lo científico en su poesía, tiene una presencia menos visible que los anteriores porque actúa de forma indirecta, quizás hasta subversiva: ${ }^{7}$ selecciona anécdotas, recurre a juicios ajenos que, tras un argumento de autoridad, apoyan sus propios puntos de vista, los comenta, los discute... y finalmente conduce al lector hasta el dilema que debe plantearse y su eventual resolución. Es difícil elegir una sola cita que ilustre este tipo de discurso, porque el aliento reflexivo y didáctico acompaña poemas enteros. Puede vislumbrarse cómo funciona en el siguiente pasaje que cierra uno de sus últimos poemas, "El origen de las especies" (2012: 284-285), donde propone un final inesperado para las teorías evolucionistas de Darwin: la confluencia espiritual de todas las especies, la prueba biológica del Reino de los cielos:

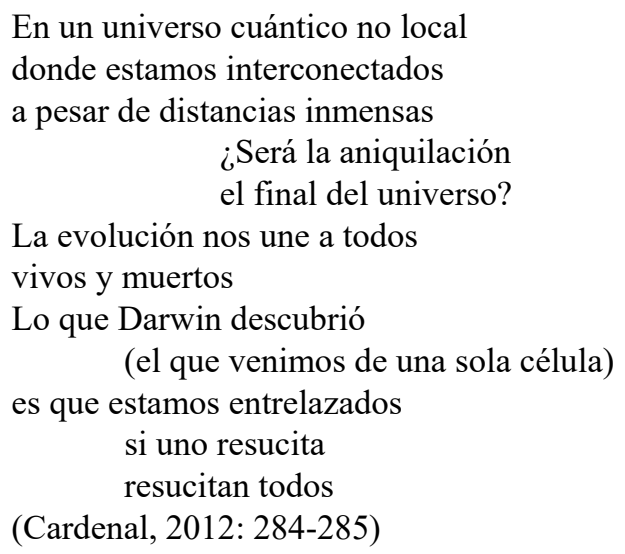

\section{La voz profética}

Esta misión interpretativa está siendo, por tanto, compartida con el lector, a quien Cardenal incorpora a sus reflexiones y de cuya íntima complicidad depende en gran medida la comunicación eficaz del texto. Veremos en seguida qué espera el autor de sus lectores, pero antes resta por hacer una reflexión última sobre

\footnotetext{
7 Muchos pasajes en los que aparece este yo didáctico serían buenos ejemplos de lo que Robert Pring-Mill (1988) llamaba "los modos de indirección" en su poesía.
} 
la presencia, todavía, de la voz profética, otra vertiente de sus discursos públicos que había sido enarbolada por la crítica como una de las banderas más representativas de la poesía del nicaragüense. Cardenal continúa fiel a ese papel de guía moral, sin abdicar de las funciones de anuncio/denuncia que lleva implícitas. "El poeta es profeta, vaticinador,/ como los monos congos que aúllan cuando va a llover", dirá en Cántico cósmico (cantiga 19), enlazando con una línea clásica en su poesía, presente en Oración por Marilyn Monroe y otros poemas (1965), Canto nacional (1972) y Oráculo sobre Managua (1973).

Es verdad que, a partir de Vuelos de victoria, el impulso profético se halla mucho más atenuado. Para Borgeson (2010: 427) este cambio se explicaba, en los años ochenta, por la transferencia al pueblo de la voz profética y el cumplimiento, con el hecho histórico de la Revolución nicaragüense, de muchos de esas profecías vaticinadas. Luego aquella fue, como dice el poeta con tristeza, una "Revolución perdida". Pero a pesar de esos saltos de la historia, Cardenal mantiene en pie el proyecto utópico que orienta toda su escritura. La denuncia sigue brotando con fuerza en poemas relativamente recientes, como "El celular", en el que su invectiva contra la injusticia, su clamor contra la sangre derramada y silenciada por la sociedad de consumo, adquiere de nuevo aliento bíblico:

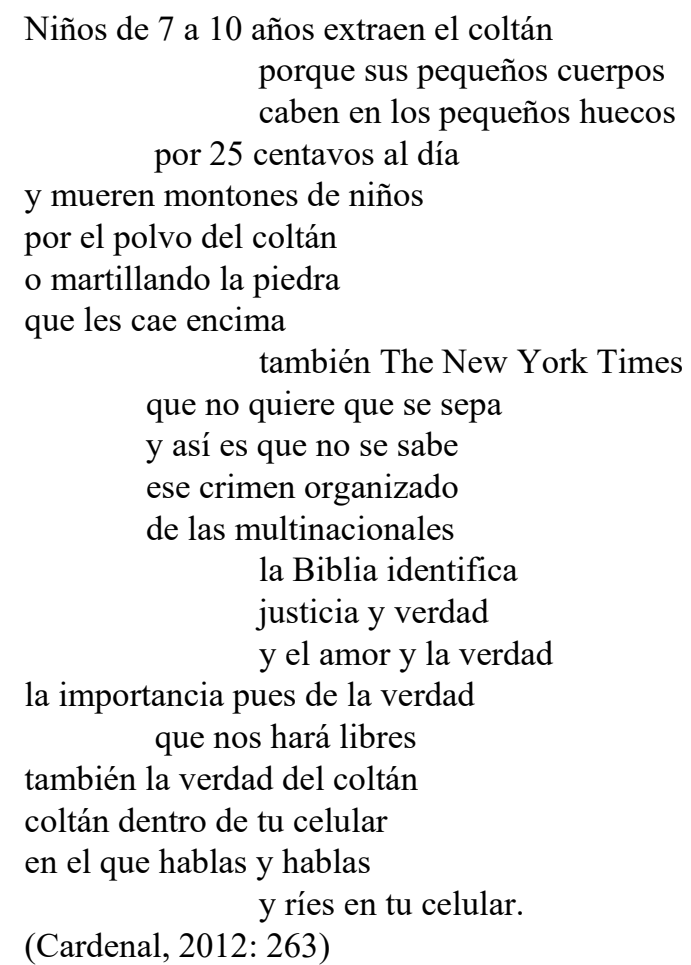

A partir de los noventa, la esperanza de un porvenir que colme las aspiraciones humanas rebasa las contingencias de orden sociopolítico y se vincula esencialmente con lo científico. Se subraya de este modo el advenimiento de una existencia de raíces espirituales, que es, con mucho, la más revolucionaria de sus profecías. El poeta-profeta entrega ya su oráculo a un auditorio sin fronteras.

\section{La voz del lector}

Precisamente al hilo de esta visión profética muchos estudios coinciden en señalar el importante papel que se atribuye al lector en la poesía de Cardenal. Se ha dicho, por ejemplo, que está obligado a abandonar su papel pasivo ante una genuina obra abierta (Fernández Retamar, 2010: 84) y se le ha llamado rotundamente lector cómplice al estilo cortaziano (Borgeson, 1984: 38). En efecto, los recursos del estilo poético de Ernesto Cardenal se orientan a una participación muy activa del lector, de modo que este descifra un mensaje estético al tiempo que asimila determinadas actitudes morales. El objetivo último de su obra consiste en implicarlo no sólo en el proceso poético, sino en un proceso liberador mucho más amplio, provocando en él un cambio de percepciones, de visión de la vida; una finalidad frecuente en lo que genéricamente se engloba bajo la ambigua etiqueta de poesía de compromiso. La lectura deviene, en último término, un acto de conciencia.

En una obra de gran extensión y complejidad como Cántico cósmico, los niveles de participación del lector son diversos y su grado de eficacia también lo es. El recurso de más envergadura que se pone en 
marcha tiene que ver con la estructura del poema, tanto en el macronivel de las secuencias temáticas o de la organización interna de las cantigas, como al nivel micro del funcionamiento de las imágenes. En cada uno de estos niveles opera eficazmente una dialéctica basada en la complementación o el contraste, que busca revelar, a través de asociaciones mentales, una realidad distinta, prístina, esencial. El emisor se reserva el derecho, como se ha comentado, de estimular estas reflexiones, cuidando el marco ético y moral en que cada pasaje descarga su impacto, y guía al receptor nada más -y nada menos- que a través de la red ideológica del poema. Por su parte, es el lector quien finalmente interpreta y dota de valores éticos lo expresado en los versos, el que tiene la responsabilidad de la construcción última del mensaje, y su reacción, aunque inducida, resulta indispensable para cargarlo de significado.

Por otra parte, en un nivel más superficial, el poeta incluye al lector en el propio texto. En ocasiones lo increpa directamente, aunque más que esperar su respuesta lo insta a hacerse preguntas, determinando incluso a quién van dirigidas esas preguntas: “¿Nació el espacio-tiempo para colapsar sin ningún plan objetivo/en el caos? Pregunto no a los cosmólogos/ sino al hombre de la calle" (cantiga 34). En otros pasajes, los apóstrofes e imperativos vuelven a recordar la intención didáctica del verso de Cardenal incorporando al receptor a la praxis ejemplificadora:

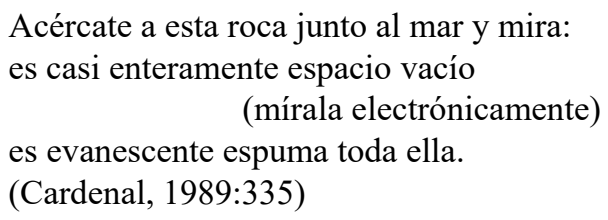

Y otro ejemplo, de Versos del pluriverso, de nuevo de corte muy epigramático:

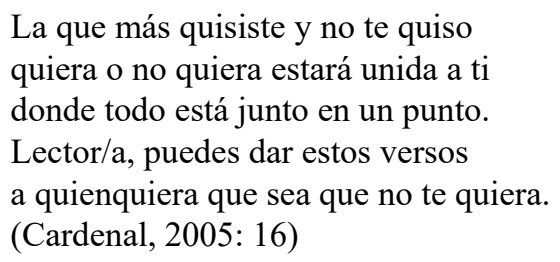

De cualquier forma, las llamadas e interpelaciones al lector -a ese tú, o vos centroamericano- son muy frecuentes, otorgándole un protagonismo que señala una relación comunicativa muy estrecha. Esto tiene que ver desde luego con esa voluntad de inteligibilidad poética que Cardenal siempre ha defendido, y tiene sus consecuencias a nivel textual: de hecho, la persona verbal preponderante en este libro es la primera del plural, con lo que finalmente la responsabilidad del discurso queda asumida por un sujeto colectivo. O de otro modo, el lector pasa a formar parte de las voces del texto como un nosotros, y se potencia la sustantividad del acto de lectura: "Si hemos aparecido nosotros haciendo preguntas ¿será/ que la intención no es que acabemos todos en un hoyo negro?" (cantiga 36). Así que el lector debe hacer más que nunca, pero también puede alcanzar más que nunca a Cardenal.

\section{7....y la del poema}

Resta aún una propuesta para finalizar esta aproximación a la multiplicidad de discursos en la poesía de Cardenal, un autor que no sólo adopta voces con funciones diversas, se textualiza a sí mismo o involucra al lector en la construcción del poema: es que también abre su obra a un despliegue intertextual que multiplica las posibilidades de la lectura. No cabe ahora detenerse en el funcionamiento de este principio constructivo, el de la intertextualidad, que es, como se dijo al principio, uno de los que mejor definen la poesía del nicaragüense, pero sí es conveniente subrayar un rasgo inusitado: la incorporación de textos que glosan el proceso de invención y escritura de la propia obra, culminando el paso del intertexto al metatexto.

A lo largo de la extensa trayectoria literaria del autor nicaragüense había sido relativamente frecuente toparse con pasajes que glosaban las nociones más genuinas de su propia poética. Pero en Cántico cósmico se introduce además información sobre la génesis y las características del propio poema, y reflexiones sobre la forma en que este va siendo escrito. De ese modo, el emisor aparece también en él como autor que reflexiona sobre la articulación de su obra, un mecanismo de escritura especular poco usual en el género. Para Jorge Alvarado Pisani (2010: 3), "las cantigas cósmicas de Cardenal constituyen una forma de holograma poético, un fractal del universo" que incluyen sus propias "llaves" o claves autorreferenciales: 
¿El orden de este poema? No tiene orden

ni desorden.

Dónde empieza la tierra y dónde acaba.

Dónde empieza y acaba una galaxia.

Nosotros: entre los electrones y las estrellas.

(Cardenal, 1989: 60)

El problema de este poema es que como el universo se expanda indefinidamente o colapse sobre sí mismo.

(Cardenal, 1989: 411)

O estos ejemplos de la última cantiga (Cardenal, 1989: 578-579):

Si el poema es poco congruente

Su tema el cosmos es menos congruente.

El Cántico no tiene fin.

Es decir, el tema del poema no termina.

Hay versos llamativos que incumben al propósito de la obra: "La conciencia salió de lo inconsciente/ En nosotros el planeta pues ama, sueña. Es la Tierra quien canta en mí este Cántico cósmico" (cantiga 20). O también: "Mis metáforas matemáticas son para defender la vida" (en la cantiga 7); "Esta mi épica astrofísica sólo tiene un sentido:/ proclamar que el universo tiene sentido" (en la 12).

Estas llamadas metapoéticas sugieren la existencia de otra voz incorporada a la multiplicidad discursiva que comentamos: la del mismísimo poema, que se explica a sí mismo al tiempo que se autoconstruye, igual que el cosmos contiene también en sí mismo sus propias claves de comprensión por el simple hecho de existir. ¿Qué ocurre? Que los lectores de Cardenal no solo se ven interpelados ante las circunstancias extraliterarias a las que remite el poema, sino ante el propio acto de lectura. Cardenal ha convertido la lectura de su obra no sólo en medio para reflexionar sobre la realidad, sino también en realidad ante la que se reflexiona.

Son muchas las voces que resuenan en el discurso poético de Ernesto Cardenal, en efecto. Y esta polifonía casa perfectamente con la personalidad carismática de quien ha debido integrar en su vida tantas contradicciones aparentes: poeta, ensayista, traductor, hombre de vocación contemplativa, sacerdote, defensor del marxismo y de la Teología de la liberación, comprometido políticamente, ministro de cultura, buen conocedor de las culturas indígenas, apasionado de la ciencia contemporánea, escultor... ${ }^{8}$ Hay muchos Ernesto Cardenal, o al menos hay muchos perfiles públicos diferentes de este hombre, y otros que sólo asomarán en la intimidad. Para mayor perplejidad de quienes tratamos de escudriñar en su obra, el poeta llegó a decir (1989: 478) que si existe vida en otros universos, será posible encontrar en ellos "poetas también con sus cantos cósmicos", y claro está, lectores de esos cantos (¿y tal vez críticos literarios...?). Una polifonía infinita, entonces, que busca ser escuchada más allá de nuestra propia galaxia, en ese pluriverso, como él lo llama, capaz de fusionar tantas voces y de acoger delicadamente un rumor del poeta en cada una de ellas.

\section{Referencias bibliográficas}

Alvarado Pisani, Jorge (2010), "Seis insinuaciones para intérpretes de las cantigas cósmicas de Ernesto Cardenal”, pág. 3. Disponible en:

\footnotetext{
${ }^{8}$ Esta faceta suya sólo últimamente ha concitado mayor reconocimiento, aunque lleva ejerciéndola más de 50 años. Dice Julio Valle Castillo (2007) que el trabajo de Cardenal ha llevado la escultura a una expresión de lo esencial, a partir de la contemplación, la conciencia y el estudio largo y profundo de los modelos. Y se podría afirmar lo mismo de su poesía: una poesía que habla de lo esencial, el amor, que parte de una actitud profundamente contemplativa y de un ingente trabajo previo -muchos años de lectura y estudio- y que pretende provocar un cambio de conciencia. Ambas son también, según el poeta, realistas y comprensibles, simples y sencillas.
} 
https://es.scribd.com/document/159057888/2010-Seis-insinuaciones-para-interpretes-de-las-cantigas-cosmicas-deErnesto-Cardenal-doc

Borgeson, Paul W. (1984). Hacia el hombre nuevo. Poesía y pensamiento de Ernesto Cardenal. Londres: Tamesis. (1992), "Diacronía y polifonía en los poemas indigenistas de Ernesto Cardenal", conferencia en Latin American Studies Association (LASA) [inédita].

(2010), "La poesía posrevolucionaria de Ernesto Cardenal", en Julio Valle Castillo (ed.). Revisiones de Ernesto Cardenal. Managua: Asociación Noruega de Escritores/Centro Nicaragüense de Escritores, págs. 417-428.

Cardenal, Ernesto (1986), "Prólogo”, en Poesía nicaragüense. Managua: Nueva Nicaragua (2ª ed.).

--------, ------- (1989). Cántico cósmico. Managua: Nueva Nicaragua.

-------, ----- (1992). Los ovnis de oro. Poemas indios. Madrid: Visor.

----- (1993). Telescopio en la noche oscura. Madrid: Trotta

---------, ------- (2005). Versos del Pluriverso. Madrid: Trotta

---------, ------ (2012). Hidrógeno enamorado. Salamanca: Eds. Universidad de Salamanca.

Carrasco Muñoz, Iván (2004), “Cántico cósmico de Cardenal: un texto interdisciplinario”, Estudios Filológicos, n. 39, págs. 129-140. Disponible en: https://scielo.conicyt.cl/scielo.php?script=sci arttext\&pid=S0071-17132004003900007

Cuadra, Pablo Antonio (1971), "Prólogo", en E. Cardenal. Antología. Buenos Aires: Carlos Lohlé, págs. 9-22.

Dorfman, Ariel (1988), "Ernesto Cardenal, ¡todo el poder a Dios-proletariado!”, en De elefantes, literatura y miedo: Ensayos sobre la comunicación americana. La Habana: Casa de las Américas, págs. 102-126.

Fernández-Retamar, Roberto (2010), "Ernesto Cardenal: el poeta y su poesía”, en J. Valle Castillo (ed.). Re-visiones de Ernesto Cardenal. Managua: Asociación Noruega de Escritores/Centro Nicaragüense de Escritores, págs. 69-86.

López-Baralt, Luce (2012). El cántico místico de Ernesto Cardenal. Madrid: Trotta.

Pastor Alonso, Ma Ángeles (1998). La poesía cósmica de Ernesto Cardenal. Huelva: Diputación.

Pérez López, Ma Ángeles (2012), "El Hidrógeno enamorado de Ernesto Cardenal”, en Ernesto Cardenal. Hidrógeno enamorado. Salamanca: Eds. Universidad de Salamanca, págs. 7-109.

Pring-Mill, Robert (1988), "El saber callar a tiempo en Ernesto Cardenal y en la poesía campesina de Solentiname", Casa de las Américas, n 166, págs.19-34

Valle Castillo, Julio (2007), "El escultor Ernesto Cardenal", Polis: revista académica de la universidad bolivariana, $\mathrm{n}^{\circ}$. 17. Disponible en: https://journals.openedition.org/polis/4324 Nicaragüense de Escritores. (ed.) (2010). Re-visiones de Ernesto Cardenal. Managua: Asociación Noruega de Escritores/Centro

Vitier, Cintio (1979), "Prólogo", en Ernesto Cardenal. Poesía. La Habana: Casa de las Américas.

Yurkievich, Saúl (1996). La movediza modernidad. Madrid: Taurus. 